\title{
A numerical study of sea breeze circulation observed at a tropical site Kalpakkam on the east coast of India, under different synoptic flow situations
}

\author{
C V Srinivas*, R Venkatesan, K M Somayaji and A Bagavath Singh \\ Radiological Safety Division, Indira Gandhi Centre for Atomic Research, Kalpakkam 603 102, India. \\ *e-mail: cvsri@igcar.ernet.in
}

\begin{abstract}
A simulation study of the sea breeze circulation and thermal internal boundary layer (TIBL) characteristics has been carried out at the tropical site Kalpakkam on the east coast of India, for operational atmospheric dispersion prediction. The community based PSU/NCAR MM5 Mesoscale meteorological model is used for the study. Three cases on typical days in summer (24 May 2003), southwest (SW) monsoon (1 July 2001) winter season (2 February 2003) with different largescale flow pattern are studied. The MM5 model is used with 3 nested domains with horizontal grid resolutions $18 \mathrm{~km}, 6 \mathrm{~km}$ and $2 \mathrm{~km}$ and 26 vertical levels. The model is integrated for 24 hours in the above cases with initial and boundary conditions taken from NCEP-FNL analyses data. Observations of 10 meteorological stations and coastal boundary layer experiments conducted at Kalpakkam are used for comparison and validation of the simulation. The characteristics of simulated sea breeze and TIBL at Kalpakkam are seen to vary in the above cases according to the prevailing large-scale winds and surface fluxes. The sea breeze circulation is seen to develop early with larger strength and inland propagation in the summer case under the influence of moderate synoptic wind and strong heating conditions than in the SW monsoon and winter cases. The horizontal and vertical extents of TIBL are found to be larger in the summer case than in other cases. Although model parameters agree in general with observations, all the fine features are not clearly captured and some slowness in model sea breeze development is also seen. The results indicate the need to improve i) the initial conditions by assimilation of available surface/upper air observations to reduce model bias and ii) surface net radiation parameterisation. The model could predict the essential features of the local circulation and further improvement is expected with better initial condition data and incorporation of more realistic surface data.
\end{abstract}

\section{Introduction}

Sea breeze is an important meteorological phenomenon in controlling the weather in coastal regions. Numerous studies on sea breeze are found in literature for the purpose of studying atmospheric pollution, convective thunderstorms, aviation safety, forecasting of forest fires (Lu and Turco 1994; Simpson 1995; Cooper et al 1998; Rao and Fuelberg 2000 among several others). Land and sea breeze is more frequently and prominently observed in tropical regions than in higher latitudes due to strong radiative heating, convection and weak coriolis force. It is attributed to the pressure gradients caused by the diurnal differential heating along the land-sea interface (e.g., Atkinson 1981; Simpson 1987). It prevails as a low-level flow from sea to land and return flow aloft from land to sea with branches of rising and sinking air motion over the land and sea respectively (Defant 1950). It is also influenced by the prevailing large-scale wind, surface heating and topographic friction.

Keywords. Mesoscale model; sea breeze; synoptic flow; thermal internal boundary layer; Sodar; Tether balloon.

J. Earth Syst. Sci. 115, No. 5, October 2006, pp. 557-574

(C) Printed in India. 
When the sea breeze circulation prevails on land, changes in the temperature structure, humidity and roughness occur in the air adjacent to the coast and lead to formation of a thermal internal boundary layer (TIBL) (Stull 1988). This effectively reduces the mixing height in the coastal regions in the daytime. Land-sea breeze circulation and TIBL are the two important phenomena that influence the pollution plume direction and diffusion in coastal regions. Many factors such as topography, synoptic flow and latitude are shown to influence the evolution and characteristics of sea breeze. Using numerical methods, Estoque (1962) has found that a zone of low-level convergence develops at the leading edge of the sea breeze current as it sets in over land. Pielke (1974) has studied the effects of topographical friction on the sea breeze evolution using a 3D numerical model. A number of studies on sea breeze considering the effects of topography, large-scale winds and coriolis force through latitude (e.g., Mahrer and Pielke 1977; Pielke 1974) followed thereafter.

Among several factors, synoptic flow, through its strength and orientation to the coast, is found to significantly influence the structure and evolution of the sea breeze (Estoque 1962; Atkinson 1981). Hunt and Simpson (1982) observed a clear formation of sea breeze convergence zones when the prevailing winds are offshore. Bechtold et al (1991) used a mesoscale model to study the influence of synoptic winds on sea breeze development. It is found that intensive sea breezes develop when the synoptic flow opposes and retards its inland propagation. The mean sea-breeze characteristics during offshore, parallel and onshore background flow regimes in east central Florida are studied from a number of sea breeze observations by Atkins et al (1995) and Atkins and Wakimoto (1997). From their study it is found that when the synoptic flow is directed onshore, the sea breeze front is weaker owing to weaker convergence. It is also found that offshore events are marked with stronger gradients of temperature and moisture and faster inland propagation speeds than the onshore/parallel events. Numerical models of varying complexity are used to study the theoretical aspects of sea breeze circulation. Liu et al (2001) used a three-dimensional atmospheric model to simulate the airflow pattern and the internal boundary layer development over the complex hilly coastline of Hong Kong. The influence of local terrain and large-scale wind on sea breeze circulation over Cleveland Bay was studied by Jianmin Ma (1997) using a two-dimensional primitive equation meso-scale model. The dynamics of boundary layer during sea breeze circulation in Athens urban environs was numerically studied by Melas et al (1995) using a higher order turbulence closure model.

The synoptic wind in India varies according to the prevailing southwest (SW) monsoon (from June to September), northeast (NE) monsoon (from October to February) systems and the westerlies during summer (from March to May). These conditions form offshore, parallel and onshore geostrophic flow situations on the east coast and influence the sea breeze development. A shallow low pressure forms on land in summer due to intense heating and convection. In an observational study at Visakhapatnam on the east coast, Ramanatham and Subbaramayya (1963) found that the sea breeze sets in very early in the daytime during the pre-monsoon (summer) season and its strength builds up by noon when the synoptic winds are offshore. The depth of the sea breeze cell is found to increase to a maximum of $500 \mathrm{~m}$ till evening at the coast. Similarly, Narayanan (1967) reported that the sea breeze activity at Trivandrum on the west coast, prevails from November to April when the winds are offshore. Sea breeze on the west coast is completely masked by the onshore strong southwesterly winds in the period from May to September (Nair and Narayanan 1980). The sea breeze frontal characteristics at Trivandrum on the west coast are investigated by Krishna Murty et al (1992) to study its impact on the aerosol concentration distribution. The aerosol concentration and columnar loading of aerosols are shown to enhance sharply due to strong updrafts associated with the passage of sea breeze front.

Kalpakkam is a tropical coastal station on the east coast of India with a gently sloping plain terrain. Land-sea breeze circulation is often observed in this region due to strong land-sea temperature contrast. A few micrometeorological experiments are conducted at Kalpakkam site to study the boundary layer structure during sea breeze time (Thara et al 2002; Sivaramakrishnan and Venkatesan 2002). These experiments revealed that TIBL forms during sea breeze hours and its depth varies between 100 and $200 \mathrm{~m}$ in the SW-NE monsoon seasons. Land-sea breeze being a local circulation, is not captured in the operational weather observations, hence modeling is essential to study its influence on the pollution dispersion. Venkatesan et al (2000) developed a simple $2 \mathrm{D}$ mesoscale atmospheric model to study the boundary layer physics and sea breeze evolution. The model is validated using Øresund landwater-land field experimental data (Thara Prabha et al 1999) and used for providing meteorological parameters for coastal dispersion. Jamima and Lakshminarasimhan (2004) made a simulation study of the sea breeze over a limited area at 


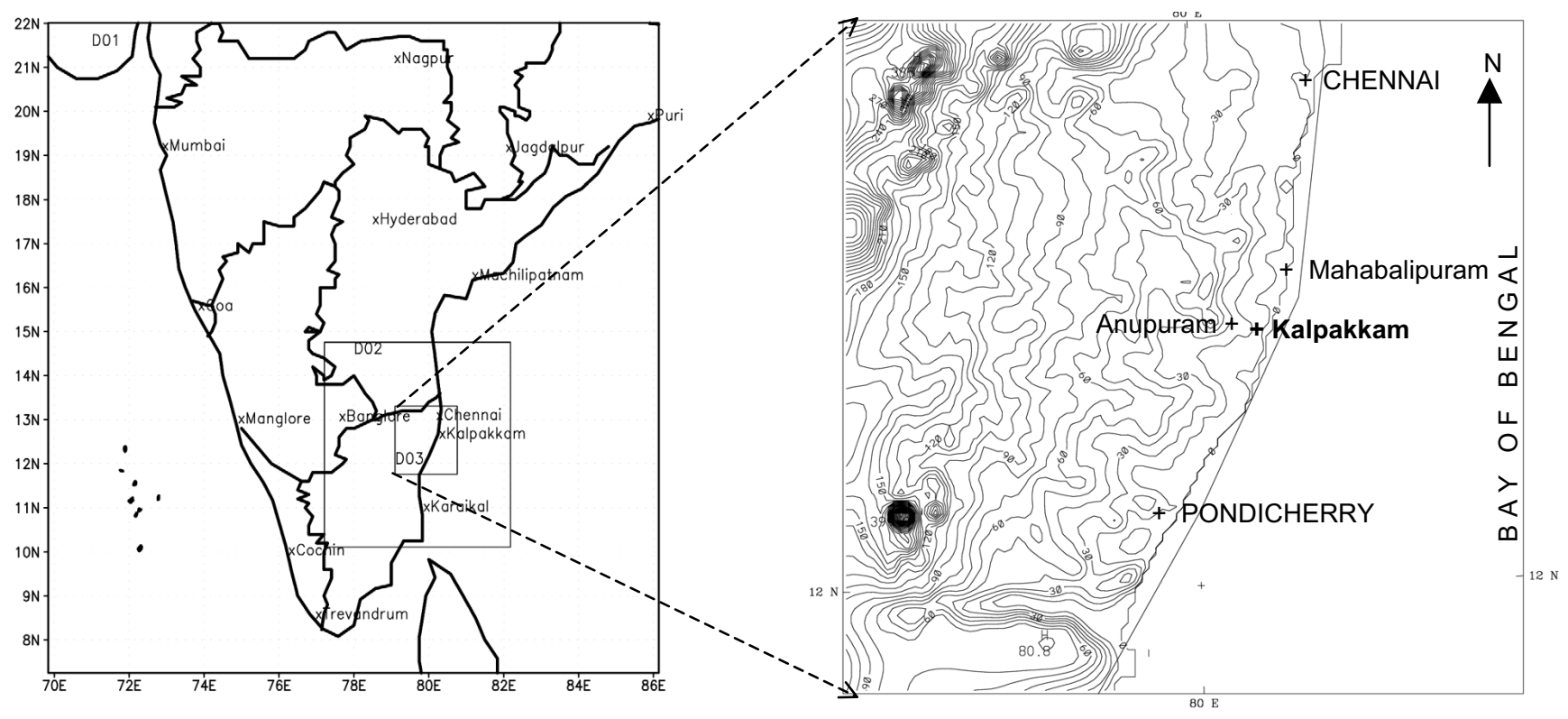

Figure 1. Domains used in MM5 model (left panel). The inset figure in the right panel shows the innermost domain covering Kalpakkam region with topographic details where the elevation contours are drawn at $10 \mathrm{~m}$ intervals.

Kalpakkam with Advanced Regional Weather Prediction System (ARPS) and compared this with some available observations. The spatial characteristics of sea breeze and TIBL, however, were not studied.

Meso-scale meteorological models are being used to provide inputs of winds, vertical temperature and stability structure, mixing depths and other parameters to atmospheric transport and dispersion models for air quality assessment in coastal/complex terrain regions. Because of the recent advances in computational speed and resolution of meso-scale models their application in realtime forecasting is increasing (Lyons et al 1995; Stauffer et al 1993; Seaman 2000). However they need evaluation for the parameters of interest for dispersion in coastal terrain (Pielke and Uliasz 1998; Shafran et al 2000). In this context, the present work is carried out to examine the suitability of a high-resolution meso-scale atmospheric model PSU/NCAR MM5 (Grell et al 1994) for the simulation of land-sea breeze circulation on the east coast for operational meso-scale atmospheric dispersion prediction. Three cases of sea breeze are studied when the synoptic flow is westerly, southwesterly and northeasterly respectively and the simulations are compared with observations. The characteristics of simulated sea breeze circulation such as onset, strength, intensity, duration, horizontal and vertical extents, and TIBL structure at Kalpakkam coast are analysed. The community based mesoscale model MM5 is used for the simulations with incorporation of nested domains and necessary physics for convection, radiation and boundary layer turbulence.

\section{Study region}

The study region is an area of $40,000 \mathrm{~km}^{2}$ around Kalpakkam nuclear site, located on the east coast of India at $12^{\circ} 30^{\prime} \mathrm{N}$ latitude and $80^{\circ} 10^{\prime} \mathrm{E}$ longitude. The site is nearly $80 \mathrm{~km}$ south of Chennai city (figure 1). The coastline is nearly linear and oriented in $\mathrm{NE}-\mathrm{SW}$ direction. The terrain is gently sloping plain land, the elevation is about $5 \mathrm{~m}$ above MSL at the coast and increases gradually to $100 \mathrm{~m}$ above MSL in $100 \mathrm{~km}$ across the coast. The soils of the region are sandy loam in texture and the vegetation comprises irrigated crops with a corresponding roughness length of $0.5 \mathrm{~m}$. The site consists of a meso-observational network of meteorological towers and sensors erected just at the coast and at Anupuram field experimental site, which is about $5 \mathrm{~km}$ inside the coast.

\section{Brief description of the model and initialization}

The model chosen for this numerical investigation is the non-hydrostatic, nested grid, primitive equation, high-resolution meso-scale meteorological model PSU/NCAR MM5. It uses a terrain following $\sigma$ vertical coordinate, i.e., the model levels near to the surface follow the terrain and gradually transform to horizontal at the model top. The horizontal grid has equal spacing in $\mathrm{x}$ and $\mathrm{y}$ directions with a staggering of velocity variables $(u, v)$ with respect to the scalars $(T, q, p)$ and vertical velocity $(w)$. The details of the model are described in 
Table 1. Details of the grids and the physics options used in the NCAR MM5 model.

\begin{tabular}{ll|l|l}
\hline Dynamics & \multicolumn{2}{c}{ Primitive equation, non-hydrostatic } \\
\hline Vertical resolution & 26 sigma levels \\
Horizontal resolution & $18 \mathrm{~km}$ & $6 \mathrm{~km}$ & $2 \mathrm{~km}$ \\
Domains of integration & $69.84^{\circ} \mathrm{E}-86.22^{\circ} \mathrm{E}$ & $77.19^{\circ} \mathrm{E}-82.18^{\circ} \mathrm{E}$ & $79.11^{\circ} \mathrm{E}-80.76^{\circ} \mathrm{E}$ \\
& $7.25^{\circ} \mathrm{N}-22.09^{\circ} \mathrm{N}$ & $10.04^{\circ} \mathrm{N}-14.90^{\circ} \mathrm{N}$ & $11.73^{\circ} \mathrm{N}-13.35^{\circ} \mathrm{N}$ \\
Radiation & Dudhia scheme for short wave radiation \\
& Rapid Radiation Transfer Model (RRTM) for long wave radiation \\
Surface processes & OSU land surface model \\
Planetary boundary layer & Mellor-Yamada (MY) level 2 turbulence closure scheme \\
Sea surface temperature & Real Sea Surface temperatures \\
Convection & Grell scheme \\
Explicit moisture & Simple Ice (SI) scheme \\
\hline
\end{tabular}

the technical note (Grell et al 1994). The prognostic region is selected with suitable horizontal, vertical resolutions and with multiple interactive domains to couple different scales of atmospheric motion for realistic simulation. The model has a number of options for physical processes of radiation, convection, atmospheric boundary layer and surface processes. In the present study three nested domains are employed in the model (figure 1, left panel). The outermost $18 \mathrm{~km}$ mesh covers Indian peninsula, the intermediate $6 \mathrm{~km}$ mesh covers the southeast coast around Chennai city and the innermost $2 \mathrm{~km}$ mesh covers the Kalpakkam region. All the domains are designed with $100 \times 100$ grids and 26 vertical levels (table 1). Fifteen vertical levels are chosen below $3 \mathrm{~km}(\sim 700 \mathrm{hPa}$ level $)$ as the phenomena of interest occurs in the lowest few kilometers. The initial and boundary conditions for the model are provided from NCEP global $1^{\circ} \times 1^{\circ}$ resolution final analyses (FNL) data. This contains horizontal and vertical winds, sea level pressure, surface pressure, temperature, specific humidity, geopotential height, soil moisture, soil temperature, sea surface temperature, skin temperature and precipitable water, etc., at every $6 \mathrm{~h}$ interval. The forecast variables include the three wind components $(u, v, w)$, temperature, atmospheric moisture, turbulence kinetic energy (TKE), vorticity, divergence, precipitation, etc., among a host of meteorological parameters. The available radiosonde observations of Chennai, Machilipatnam and Karaikal are assimilated using the objective interpolation scheme in MM5 to prepare high resolution initial conditions, but improvement is not noticed which is probably due to the above observations already being used in NCEP final analyses. The model is initialized at 0000 Indian Standard Time (IST) on each of the selected days and integrated for 24 hours. The lateral and bottom boundary conditions in the model are updated at every 6-h integration. For the atmospheric boundary layer the Eta Mellor-Yamada scheme
(Janjic 1990) is used. It includes a prognostic equation for TKE and applies local vertical mixing. The turbulent exchange coefficients are determined in terms of TKE. The surface temperature is predicted using a land surface model (LSM) (Chen and Dudhia 2001). Before the LSM the surface layer exchange coefficients are calculated using similarity theory and after the LSM it calculates vertical fluxes with an implicit diffusion scheme. The surface boundary values for terrain height, albedo, moisture availability, emissivity, roughness coefficient, thermal diffusivity of soil are specified from USGS data and interpolated to the model grids. For the $2 \mathrm{~km}$ grid mesh the above data are specified at $0.9 \mathrm{~km}$ resolution. The upper boundary condition is radiative in all the domains. In the model outer grids the Grell (1993) convective parameterisation is used. Atmospheric radiation and cooling rates are calculated every $30 \mathrm{~min}$ using simple cooling schemes based on temperature.

\section{Field experiments}

A series of coastal atmospheric boundary layer experiments (CABLE) were conducted at Kalpakkam on the east coast in SW and NE monsoon seasons during 2001-2002 to study the coastal boundary layer and sea breeze characteristics in a joint field campaign by scientists from Indian Institute of Tropical Meteorology, Pune, IGCAR, Kalpakkam, Indian Institute of Technology (IIT), Delhi and Andhra University, Visakhapatnam. Extensive data on wind, temperature and humidity in the boundary layer were collected using a Tether balloon system, Doppler Mini-SODAR and a $50 \mathrm{~m}$ meteorological tower at the experimental site 'Anupuram' located $5 \mathrm{~km}$ northwest inside the coast from Kalpakkam. The data are being continuously collected for site characterization. These observations are used for validating the simulations in the Kalpakkam region (3rd domain). Over 

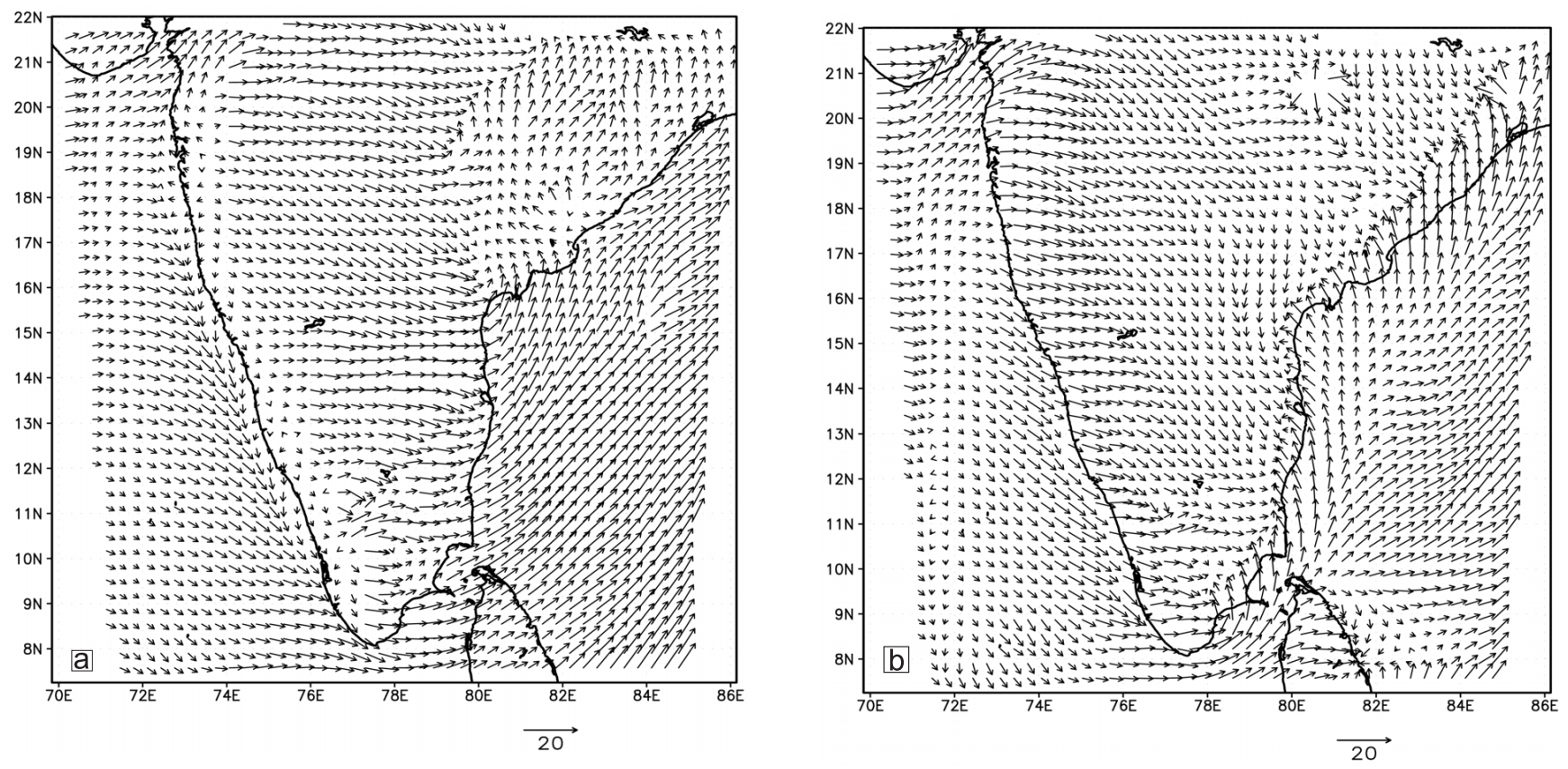

Figure 2. Simulated surface wind over Indian peninsula (at $\sigma=0.995, \sim 20 \mathrm{~m}$ AGL) at (a) 0600 IST and (b) 1400 IST on 24 May 2003.

a larger region (domain 1) the simulation is compared with radiosonde observations collected from operational weather stations of the India Meteorological Department.

\section{Analysis of the results}

The simulation is conducted for 24 May 2003, 1 July 2001 and 2 February 2003 respectively which are considered to be representative of summer, SW monsoon and winter seasons in the study region. A number of observations are gathered at Kalpakkam on these days in field experiments. While analyzing nested model simulation, the focus is mainly on the results of the innermost nest. However, as the simulation in the outer domain would influence results in the inner domains, and since the outer domain covers a wider perspective of the thermally induced coastal circulations, the results from outermost nest are also discussed briefly. The case study for 24 May 2003 is discussed first followed by 1 July 2001 and 2 February 2003.

\subsection{Summer case}

\subsubsection{Flow field in the Indian peninsular region}

The southwest monsoon had set in over Kerala on 8 June 2003. The low-level wind flow up to $1.5 \mathrm{~km}$ was westerly to southwesterly a few days before the onset of the monsoon. There was a low-pressure formation in the Bay of Bengal on 13 May 2003, which subsequently dissipated into a trough on the central east coast. The synoptic wind was moderate in strength. Simulated wind field on 24 May in the larger region, i.e., domain 1 indicates the presence of westerly to northwesterly winds along the west coast, westerly winds over central parts and southerly/southwesterly winds over Bay of Bengal at 0600 IST (figure 2a). Simulated surface wind in the afternoon at 1400 IST indicates a change in the circulation pattern in oceanic region adjacent to the east coast and development of sea breeze circulation along the east coast (figure $2 \mathrm{~b}$ ). The influence of sea breeze is seen on the flow pattern several hundred kilometers adjacent to the coast. It is seen to spread inland 60 to $150 \mathrm{~km}$ along the east coast at 1400 IST (figure 2b). The direction of sea breeze incidence is seen to vary along the coast according to the variation in the coastline curvature and latitude. Since the large-scale wind along the west coast is onshore the onset and progress of sea breeze could not be clearly distinguished from the synoptic flow. While there is no directional change in the simulated surface wind, its strength is seen to increase from $6 \mathrm{~m} \mathrm{~s}^{-1}$ to $8 \mathrm{~m} \mathrm{~s}^{-1}$ towards the afternoon.

The PBL depth over tropical land generally increases during day and falls rapidly during night and exhibits a diurnal oscillation. The top of tropical PBL is generally marked with a weak inversion and forms its upper limit. As the sea breeze penetrates inland, vertical ascent of air occurs at the sea breeze leading front and subsidence on the rear side of it, thus causing the PBL top to 

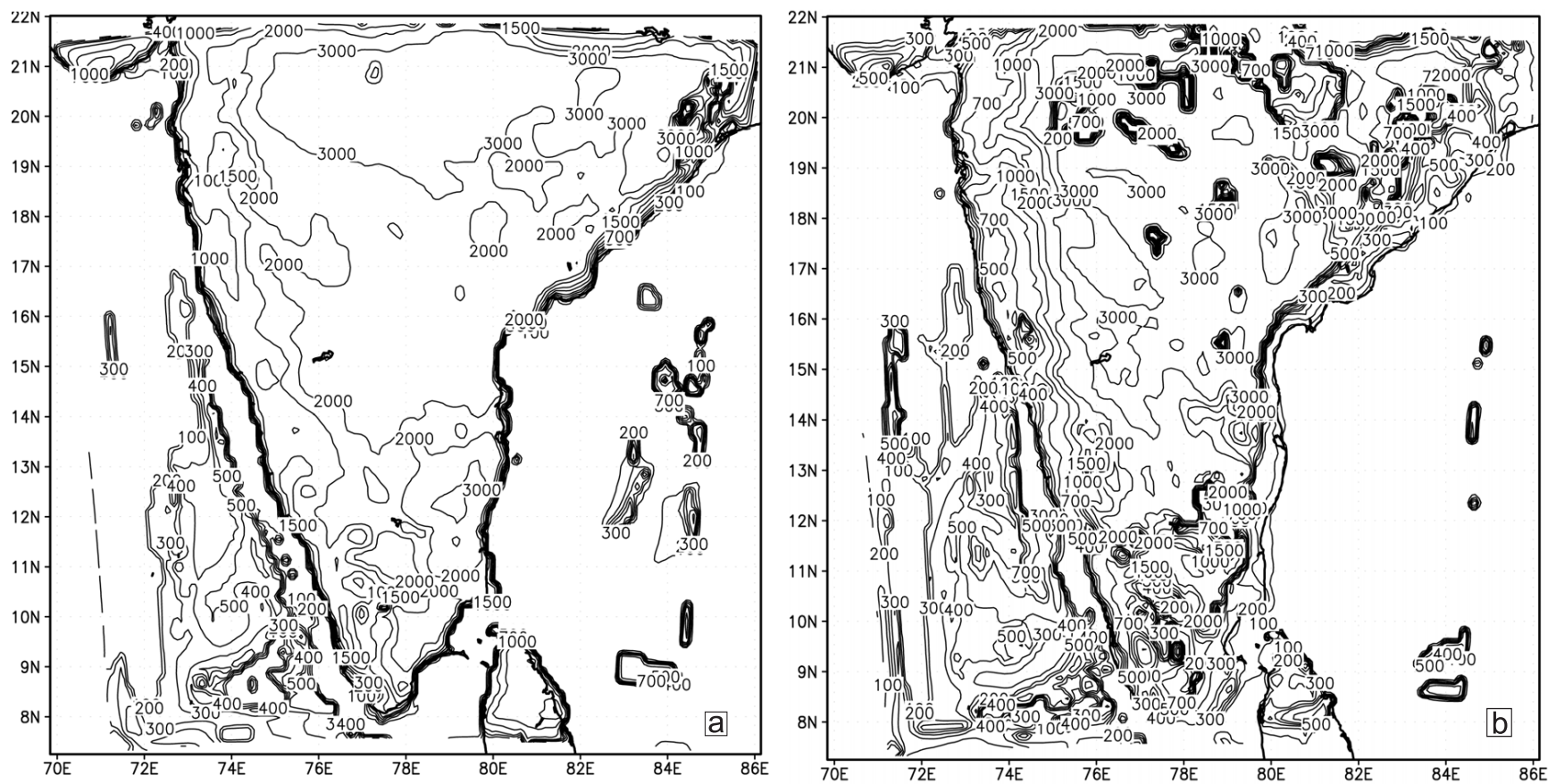

Figure 3. Simulated boundary layer height (m) over Indian peninsula at (a) 1400 IST, (b) 1800 IST on 24 May 2003.

slope downwards from land to sea. It is seen from the simulation that the boundary layer height over the coastal land is about $2000 \mathrm{~m}$ at 1400 IST (figure $3 \mathrm{a}$ ). With the advection of sea breeze the mixing height at the coast is seen to reduce sharply to $200-400 \mathrm{~m}$ towards 1800 IST (figure $3 \mathrm{~b}$ ). The model results in the larger region are validated with radiosonde observations from a few operational weather stations falling in this region (Chennai, Karaikal, Cochin, Trivandrum, Mangalore, Bangalore, Hyderabad, Machilipatnam, Raipur and Nagpur). As the radiosonde data has been used in NCEP-FNL analyses, which is subsequently used for updating the boundary conditions, the model results are sampled for comparison before the model adjusts the boundary conditions. A qualitative agreement of the model parameters for wind, temperature and relative humidity with radiosonde data is shown as an example for Chennai location (figure 4) on the east coast. The model predicted atmosphere at Chennai is less stable than the observed state up to $1 \mathrm{~km}$ height. The wind is slightly underpredicted below $500 \mathrm{~m}$ height and slightly overpredicted above $500 \mathrm{~m}$. Relative humidity from the model on this cloudless day is roughly $10 \%$ less than the observations up to $750 \mathrm{~m}$ height. The differences in the simulation and observations are attributed to the time-volume averaging in the model and are not gross deviations from the actual state. A quantitative comparison of the model parameters with the radiosonde observations of the above stations is made following the Willmott et al (1985) method. Here, correlation and standard deviation are estimated from the observations, and model values are sampled at standard pressure levels $(1000,925,850,700$ and $600 \mathrm{hPa}$ ) at 0600 and 1800 IST. For wind speed, wind direction, potential temperature and relative humidity the correlation coefficient and standard deviation are found to be $(0.818,2.059),(0.724$, $49.3),(0.90,2.846)$ and $(0.654,8.05)$ respectively. These statistics provide an abstract indication of the model's ability to reproduce the observed characteristics at various locations. Hence, the results are examined in detail from the inner domain with respect to the evolution of the flow field and boundary layer characteristics.

\subsubsection{Flow field in the Kalpakkam region}

The evolution of the simulated near-surface $(\sim 20 \mathrm{~m} \mathrm{AGL})$ wind field is shown in figure 5 at four hours 0400, 1200, 1400 and 1800 IST when the conditions are considered to be representative of stable night time, day time, sea breeze and evening conditions respectively. Low-level winds are seen to vary diurnally and spatially in the innermost domain. This flow variability is also seen over the marine boundary layer adjacent to the coast.

It is seen that the model could bring out the contrast between night time and day time surface winds in the simulation from the innermost nest covering the Kalpakkam region. The surface wind field is weak southwesterly to westerly at 0400 IST and northwesterly at 0600 IST. The winds are offshore along the coast indicating development of 

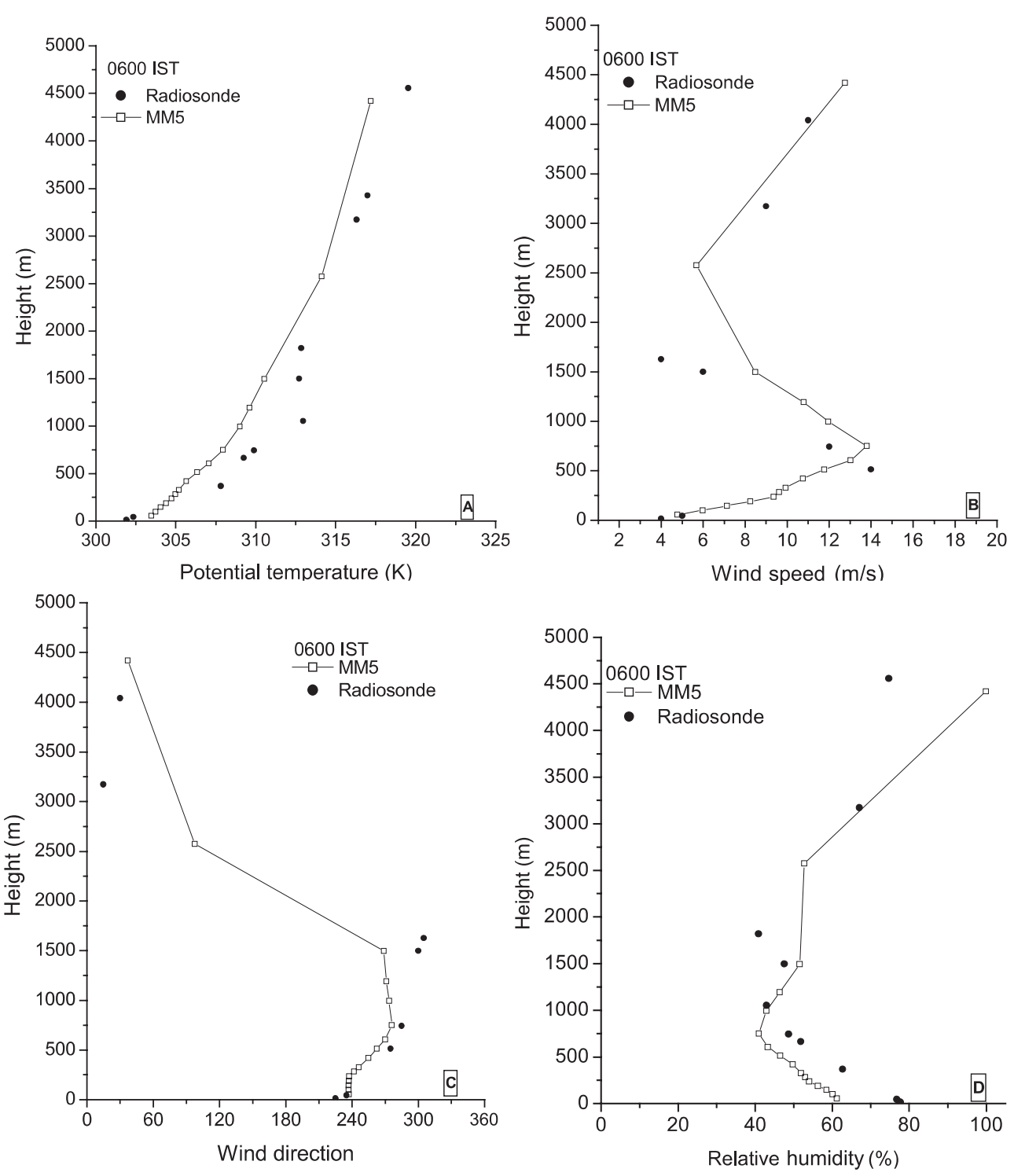

Figure 4. Comparison of simulated and observed (a) potential temperature, (b) wind speed, (c) wind direction, (d) relative humidity corresponding to Chennai location on 24 May 2003.

land-breeze circulation. The surface wind during noon is seen to turn southeasterly and enter land at 1300 IST indicating the onset of sea breeze (figure 5c). This transition in the surface wind field during sea breeze onset time is not clearly seen in the results of the outer domain. In the subsequent hours the sea breeze is seen to propagate further inland to a distance of about $90 \mathrm{~km}$ towards the evening (figure 5d). Regions of strong horizontal convergence (negative divergence) are seen at the sea breeze-land breeze confluence zone, which can be identified as the sea breeze front region. It is marked with wind blowing distinctly in opposite directions across it. A weak wind region $\left(\leq 2 \mathrm{~m} \mathrm{~s}^{-1}\right)$ is also seen ahead of the front, which is due to the opposing influence of the sea breeze on the prevailing wind.
Figure 6 shows the diurnal variation in modeled and observed wind speed, wind direction at $10 \mathrm{~m}$ level and surface heat flux sampled at the model grid corresponding to experiment site 'Anupuram' which is about $5 \mathrm{~km}$ from the Kalpakkam coast line. The observations indicate an increase in wind speed (from $2 \mathrm{~m} \mathrm{~s}^{-1}$ to $7 \mathrm{~m} \mathrm{~s}^{-1}$ ) and shift in wind direction from $270^{\circ}$ (westerly) to $150^{\circ}$ (southeasterly) in the noon under the influence of the sea breeze onset. These plots indicate that the model values differ from observations at 1200 IST due to a delay in the simulated wind field. A significantly lower sensible heat flux is found in the model in the forenoon (figure 6c), which reduces convection and turbulence generation and hence lead to delay in the setting up of the sea breeze circulation. The surface fluxes would also depend on 

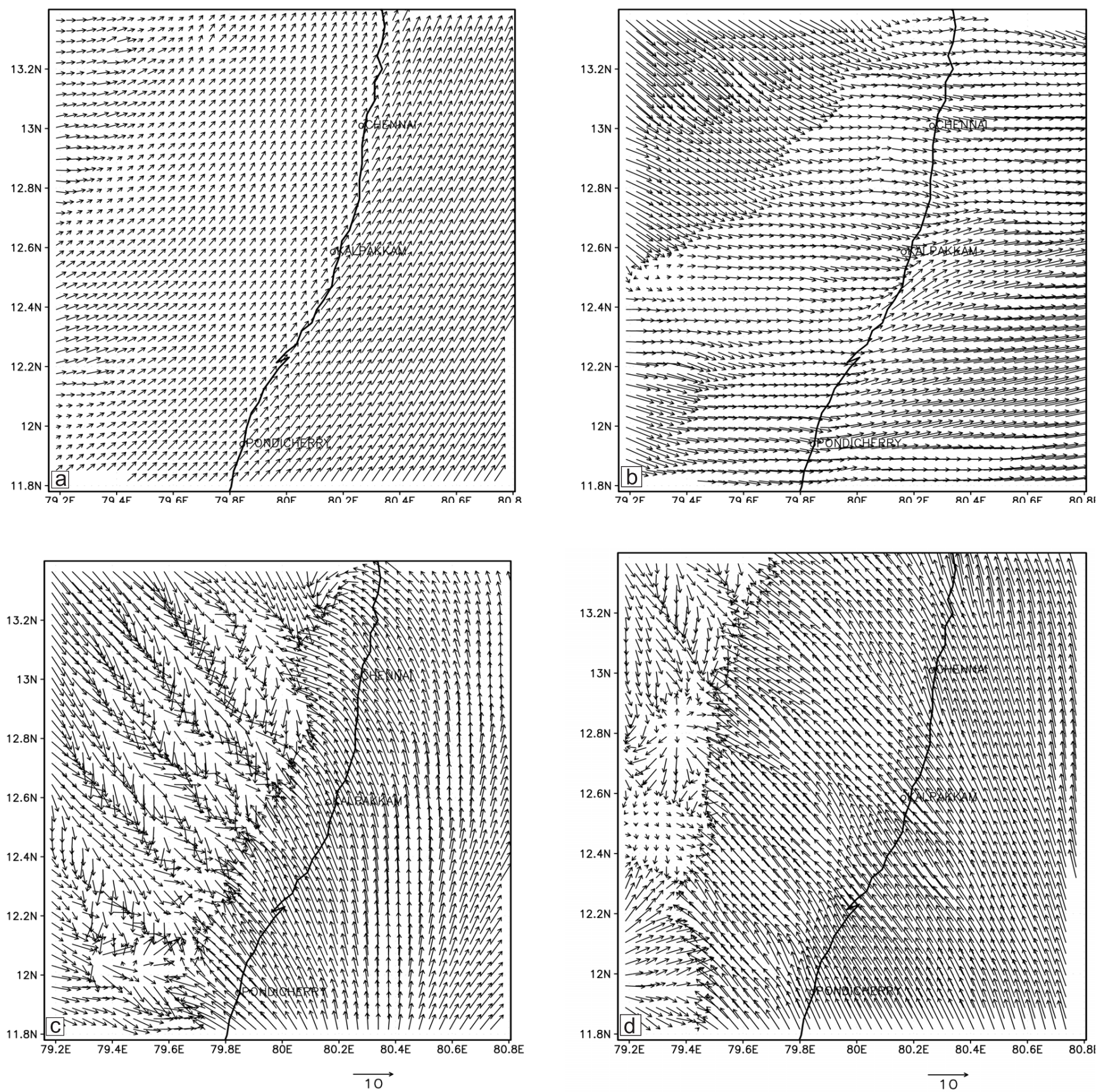

Figure 5. Simulated surface wind field (at $\sigma=0.995, \sim 20 \mathrm{~m}$ AGL) (a) 0400 IST, (b) 1000 IST, (c) 1400 IST and (d) 1800 IST in the Kalpakkam region on 24 May 2003.

the representation of the vegetation and soil types apart from soil moisture initialization. A more representative data of vegetation and soils would be needed to reduce the model bias in the simulation of surface processes. A modification of initial soil moisture would also be necessary for treatment of turbulent fluxes and to improve the simulation further. Vertical profiles of simulated and observed wind from Doppler Mini-Sodar are shown in figure 7 . The plots for wind speed and direction indicate that the trends of the simulated and observed wind differ between 1100 and 1400 IST due to a slow evolution of the model sea breeze by about $1 \frac{1}{2}$ hours. Model wind is westerly and underpredicted at 1200 IST whereas Mini-Sodar measured wind profiles indicate the presence of south-southwesterly winds. These results indicate that the model-simulated sea breeze is slower than the observed one by a few hours. The error in wind field simulation is likely to leave significant impacts on local weather and dispersion forecasts. 

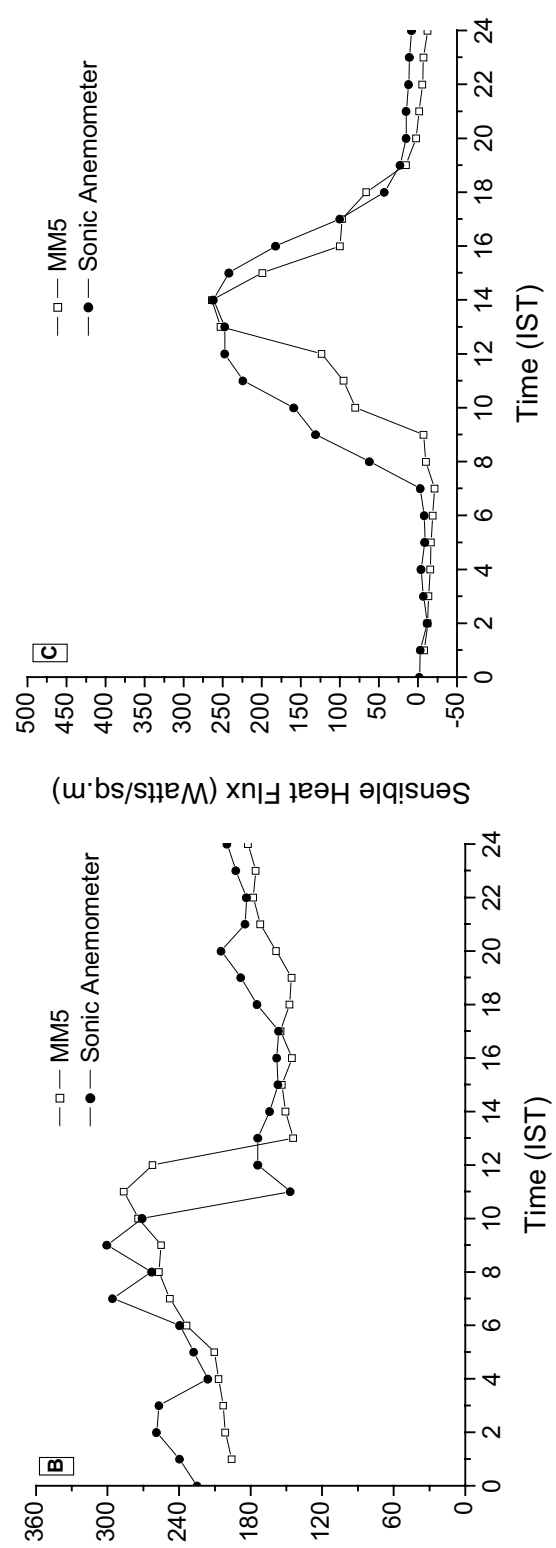

(sәәцбәр) ио!ฺәәц!р pu!M

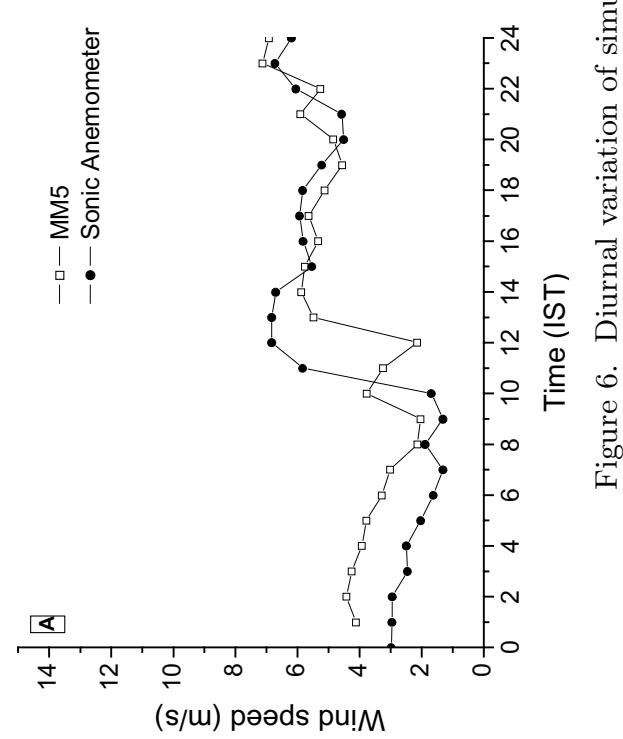

\subsubsection{Impact of the sea breeze circulation on the coastal PBL}

The spatial distributions of potential temperature and TKE reveal the changes in the coastal PBL due to sea breeze occurrence. These are examined in a vertical cross-section in NW-SE direction across the coast. The stability structure of the boundary layer is altered when air from a cold-water surface passes over a warmer land surface. An adjustment also occurs in the advecting air according to the change in the surface roughness. These alterations lead to the formation of TIBL (Gryning and Batchvarova 1990). It is a shallow unstable layer with a neutral or stable layer aloft. When TIBL forms, it limits the vertical spread of pollutants in coastal regions. Hence its horizontal and vertical structure is examined from the simulation.

The simulated temperature distribution after the sea breeze onset (1500 IST) at the coast is seen to be much different from the early morning stable boundary layer and day time convective unstable layer (figure 8a). Adjacent to the coast a shallow unstable layer is seen to develop which gradually merges with the generic inland boundary layer. Over the sea a stable boundary layer is seen at this time. The vertical growth of the internal boundary layer depends on the convective and mechanical turbulence (Gryning and Batchvarova 1990). A modification in TKE distribution is seen across the land-sea interface (figure $8 \mathrm{~b}$ ). The TKE gives a measure of the vertical extent of TIBL. The simulated temperature profiles indicate that the TIBL started developing after 1300 IST, and its horizontal extent reached a maximum at 1700 IST. The vertical extent of TIBL as seen from the base of the lowest inversion in temperature profiles (Arritt 1987 ) is about $250 \mathrm{~m}$ at 1500 IST and is seen to extend up to $40 \mathrm{~km}$ inland (figure 9).

\subsection{Southwest monsoon case}

The large-scale wind in July is governed by the Indian summer monsoon. Radiosonde observations from Chennai location for wind speed and direction are shown for 1 July 2001 in figure 10. These vertical profiles for wind show the presence of westerly and southwesterly wind in the lower levels in the morning (0530 IST) and easterly wind in the afternoon (1730 IST) respectively. The profiles also show strong winds of about 5 to $8 \mathrm{~m} \mathrm{~s}^{-1}$ near to the surface.

From the simulation on 1 July 2001 in domain 1 , it is seen that the low level (sigma $=0.995$, $\sim 20 \mathrm{~m}$ AGL) wind flow is strong westerly over the land region at 0600 IST. As the heating over land increases gradually towards noon the surface wind is seen to turn southeasterly. Towards 

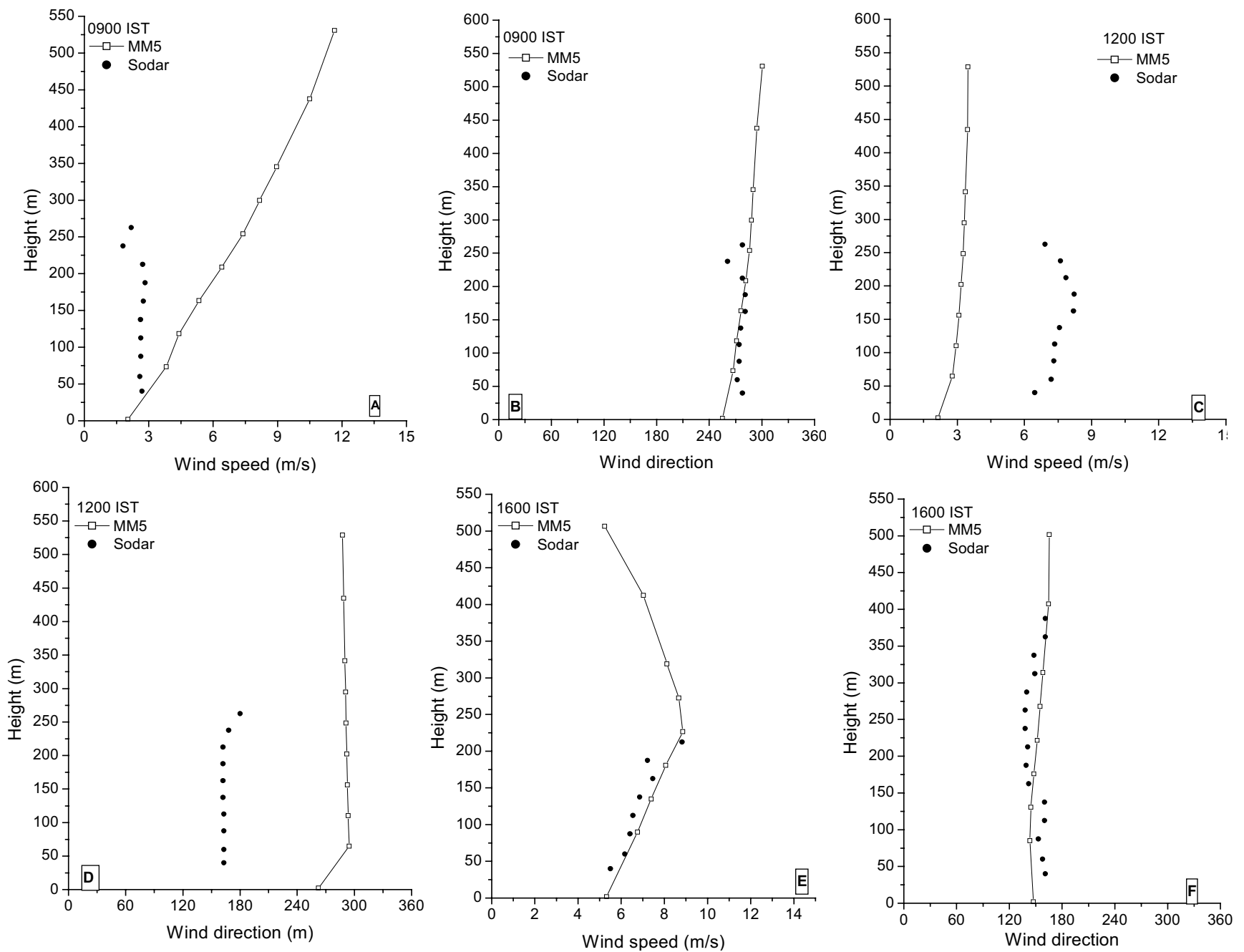

Figure 7. Comparison of vertical profiles of simulated and sodar observed wind speed and direction at 0900 IST (A, B), 1200 IST (C, D) and 1600 IST (E, F) respectively corresponding to the numerical grid at Anupuram experimental site on 24 May 2003.

the late afternoon sea breeze development is seen at 1600 IST on the east coast (not shown) and is recognized from the onshore winds along the coast.

The simulated surface wind field for the Kalpakkam region is shown in figure 11 for 0800 , 1400, 1800 and 2200 IST which are considered representative of the morning, convective day time, evening transition and stable night conditions respectively. It is seen that the surface wind is southwesterly up to 1400 IST over the land. The wind over the marine boundary layer is seen to turn southeasterly at 1400 IST, however it is not established over the land region. Due to slow progress, the onset of sea breeze is noticed at 1600 IST at the coast. The flow is not well organized as in the case of summer and it is confined only to a few pockets at the coast. Its maximum extent is about $20 \mathrm{~km}$ inland towards late evening. The model wind corresponding to the Kalpakkam grid is compared with tower measurements at $10 \mathrm{~m}$ level (figure 12). The observations are averaged hourly. Both the tower and the model show southwesterly wind till 0900 IST and westerly wind between 1000 and 1500 IST. Although a delay of about one hour is seen in the model wind evolution, the model values as well as the observations indicate southeasterly winds (sea breeze) after 1600 IST. The surface wind is overpredicted till 0900 IST and thereafter agrees closely till 1400 IST. A shift in the surface wind direction from $270^{\circ}$ to $100^{\circ}$ is seen in the simulation at 1600 IST, which is also noticed in the observations. From the profiles of simulated potential temperature across the coast (not shown), it is seen that the first few vertical profiles indicate the formation of a shallow and strongly unstable layer indicating TIBL development to a height of about $100 \mathrm{~m}$ and extending horizontally to $15 \mathrm{~km}$ inland. 

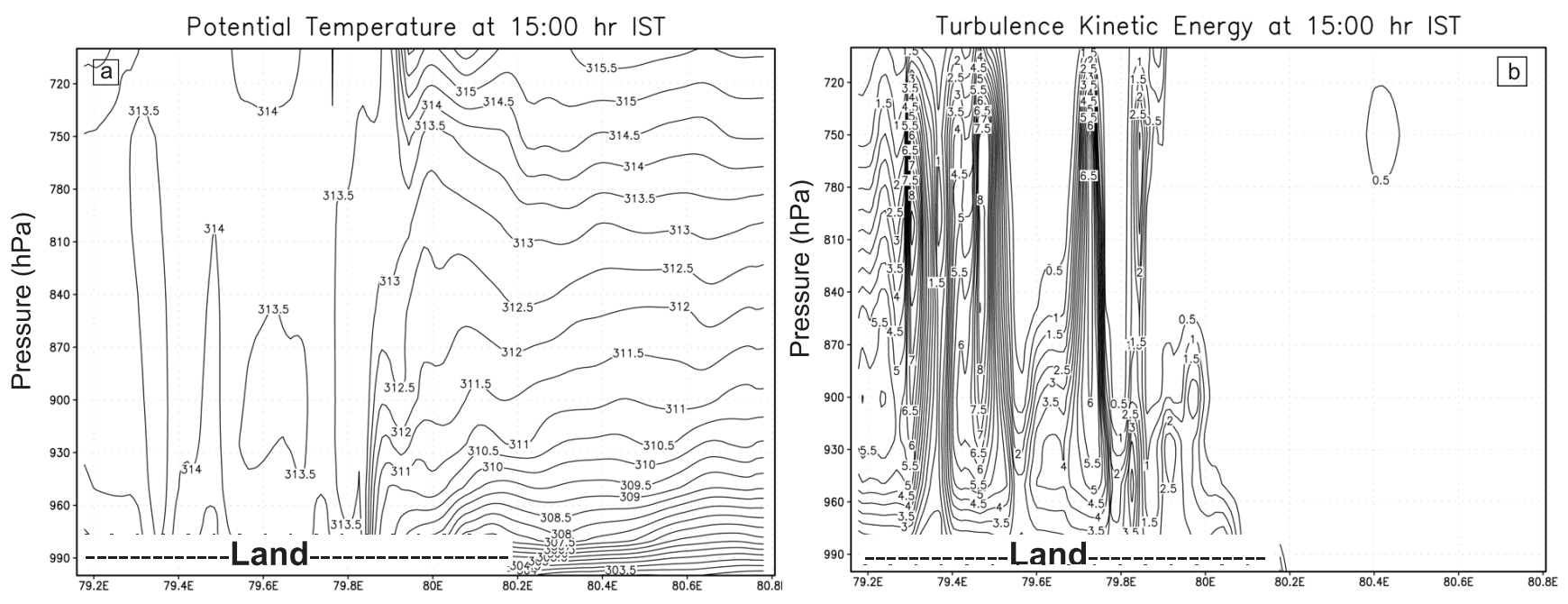

Figure 8. Simulated spatial distribution of (a) potential temperature and (b) TKE $(\mathrm{J} / \mathrm{kg})$ in a vertical cross-section across the Kalpakkam coast at 1500 IST on 24 May 2003.

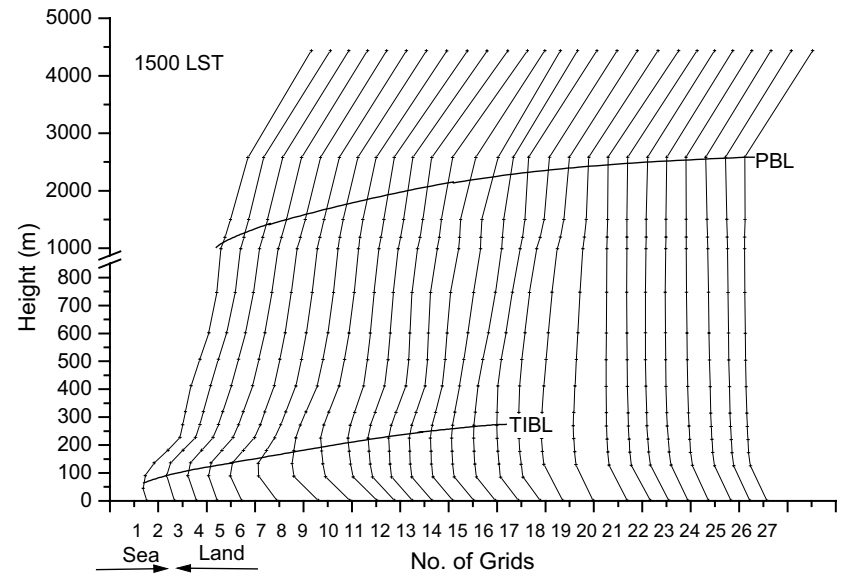

Figure 9. Vertical profiles of simulated potential temperature across Kalpakkam coast at 1500 IST on 24 May 2003. Kalpakkam location falls on grid no. 3.

\subsection{Winter (north-easterly synoptic flow case)}

The simulation for the winter season case was performed on 2 February 2003 when the prevailing synoptic wind was northeasterly and onshore in the study region. The strength of the large-scale wind is $2-4 \mathrm{~m} \mathrm{~s}^{-1}$. The simulated surface wind in the morning hours in the outermost domain is calm northwesterly $\left(\sim 2 \mathrm{~m} \mathrm{~s}^{-1}\right)$ on the east coast and indicates the prevalence of land breeze. It is seen to shift easterly at 1200 IST indicating onset of sea breeze (not shown). The onset timing, extent of sea breeze circulation on the east coast are seen in more detail from the simulation from the innermost domain covering Kalpakkam region (figure 13). Here, the surface wind is weak westerly (land breeze) in the morning time. It is seen to shift north-northeasterly direction at 1000 IST under the influence of the synoptic wind. An organized flow from sea to land in the northeasterly direction is established at 1400 IST with strong winds $\left(>4 \mathrm{~m} \mathrm{~s}^{-1}\right)$ indicating onset of sea breeze. The flow is seen to become stronger $\left(\sim 6 \mathrm{~m} \mathrm{~s}^{-1}\right)$ over land after 1400 IST and a convergence region $\left(\sim 100 \mathrm{~s}^{-1}\right)$ is also seen to develop at the leading front (figure 13). The extent of sea breeze is seen to be about $50 \mathrm{~km}$ by 1600 IST. Thus the simulation shows that the low-level winds at the coast in this case are northeasterly about $60 \%$ of the day time. The sea breeze is seen to set at the coast in the northeasterly direction. It is difficult to differentiate the sea breeze in this case as it is masked completely by the prevailing synoptic wind. However the onset of sea breeze can be understood from the gain in the wind speed at the coast apart from the direction sense.

The diurnal boundary layer wind pattern is analysed from the time-height cross-section of winds (not shown) for the numerical grid at Kalpakkam location. Winds up to the vertical level $(\sigma=0.94)(\approx 500 \mathrm{~m})$ are considered as low-level winds. Calm winds are seen to prevail (2.5 to $3 \mathrm{~m} \mathrm{~s}^{-1}$ ) between 0000 to 0900 IST, which become stronger $\left(>4 \mathrm{~m} \mathrm{~s}^{-1}\right)$ after 1400 IST. The maximum surface winds are seen during the sea breeze regime. The diurnal variation of winds is seen to decrease with height and above $1 \mathrm{~km}(\sigma=0.9)$ it is negligible.

The simulated surface wind at $10 \mathrm{~m}$ level at Kalpakkam numerical grid is plotted against the observations (figure 14). Simulated wind very closely followed the observations except in the morning hours when the model slightly 

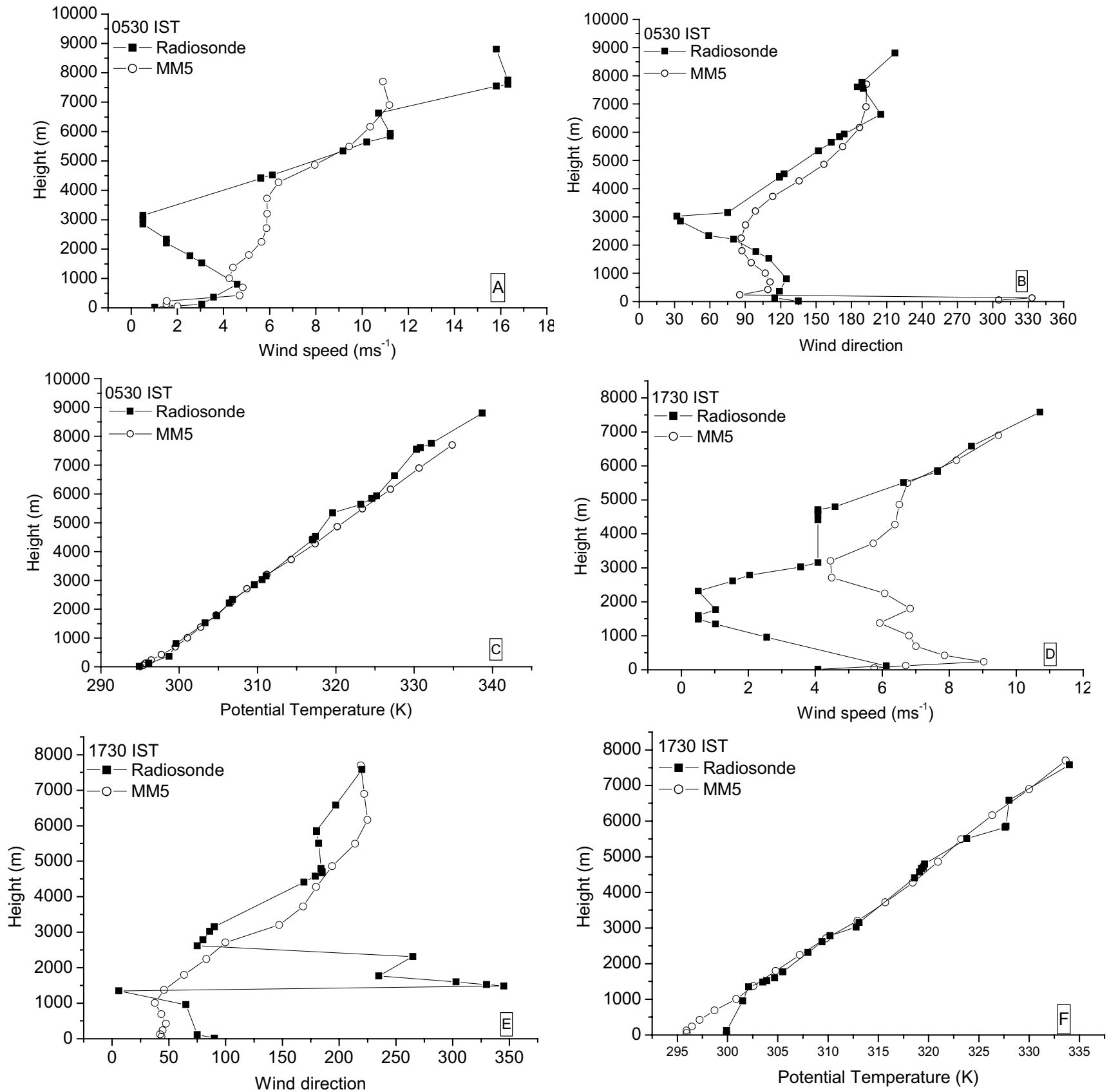

Figure 10. Comparison of model vertical profiles and radiosonde observations of wind speed, wind direction and potential temperature at 0530 IST (A, B, C) and 1730 IST (D, E, F) respectively for Chennai location on 1 July 2001.

over predicted the surface winds. The direction of the simulated wind slightly deviates from the observed wind between 0900 and 1100 IST. Once again, as in the summer case, observations indicate a delay by about an hour in the onset timing of sea breeze in the model. From the simulated profiles of potential temperature at Kalpakkam coast at 0600, 1100 and 1400 IST the atmospheric stability structure in the morning, pre-sea breeze and sea breeze conditions are seen. From the profile at 0600 IST the existence of a stable layer marked by a steep inversion up to $200 \mathrm{~m}$ AGL is seen. The profiles in the subsequent times indicate convective unstable conditions. A transition from shallow unstable layer to steep unstable layer in the lower levels is seen from the profiles at 11 and 1400 hours respectively. This modification is due to the development of TIBL at the coast. The depth of TIBL as seen from the simulated potential temperature profiles across the coast increases from $50 \mathrm{~m}$ at the coast to about $150 \mathrm{~m}$ at $20 \mathrm{~km}$ away at 1500 IST (not shown). This is also seen from the drop in the 

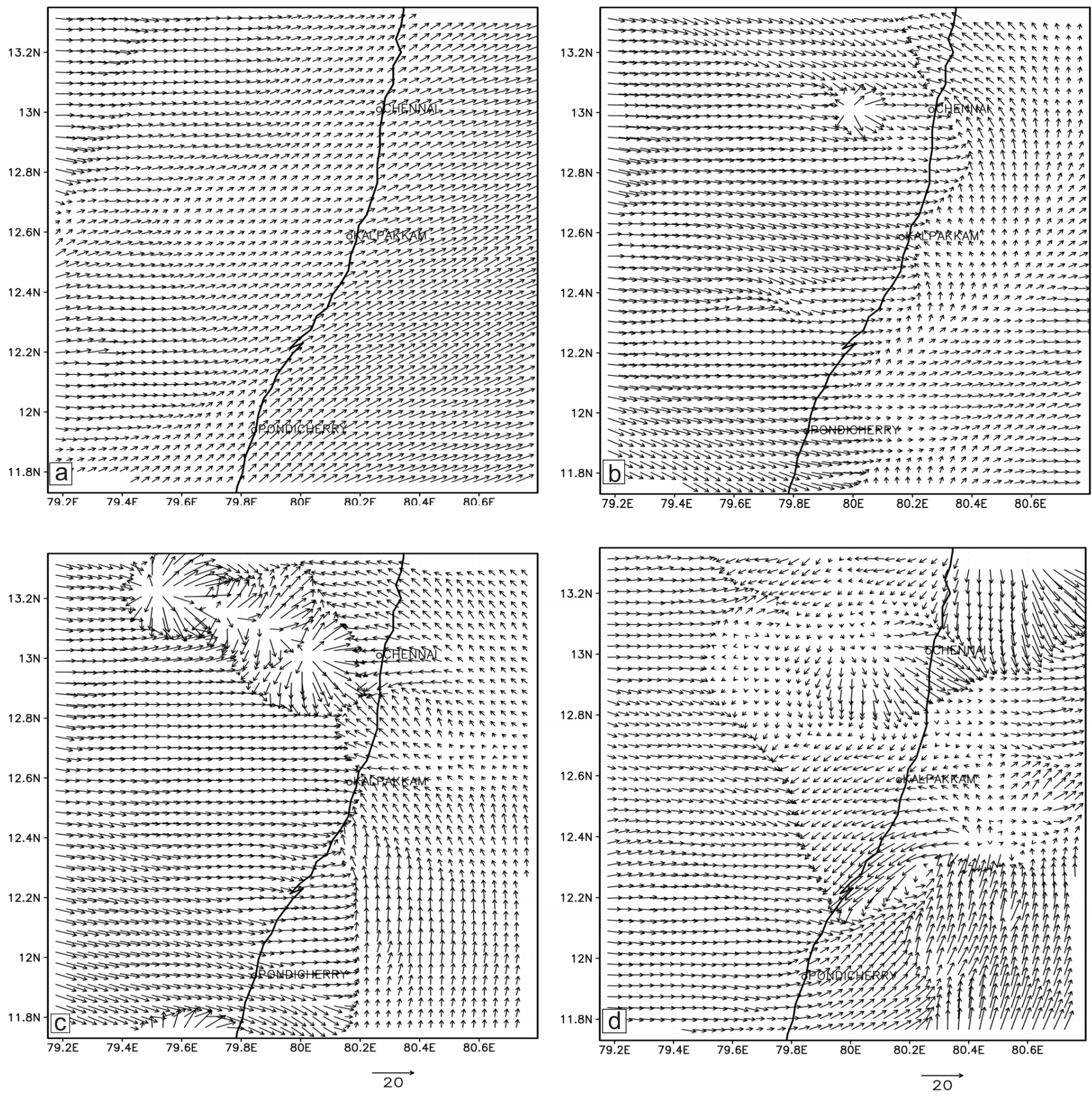

Figure 11. Simulated surface wind in the Kalpakkam region (at $\sigma=0.995, \sim 20 \mathrm{~m}$ AGL) at (a) 0800 IST, (b) 1400 IST, (c) 1800 IST and (d) 2200 IST respectively on 1 July 2001.

simulated mixing height from $1200 \mathrm{~m}$ at the inland position to $100 \mathrm{~m}$ just near to the coast at 1500 IST. The area of this low mixing height can be identified as the region of TIBL influence.

\section{Discussion}

Thus the simulation study in the three different seasonal cases clearly indicates that the sea breeze characteristics at the tropical coastal site
Kalpakkam are mainly influenced by the synoptic flow. The intensity, strength and inland penetration of sea breeze are found to be higher in the summer than in SW monsoon and winter seasons. During winter the sea breeze is merged in the NE synoptic flow and its onset could be identified from higher wind speeds in the afternoon. The variation in the surface fluxes in different seasons (table 2, figure 15) also influences the local sea breeze pattern. It is seen that the net outgoing fluxes of sensible and latent heat are higher in the 

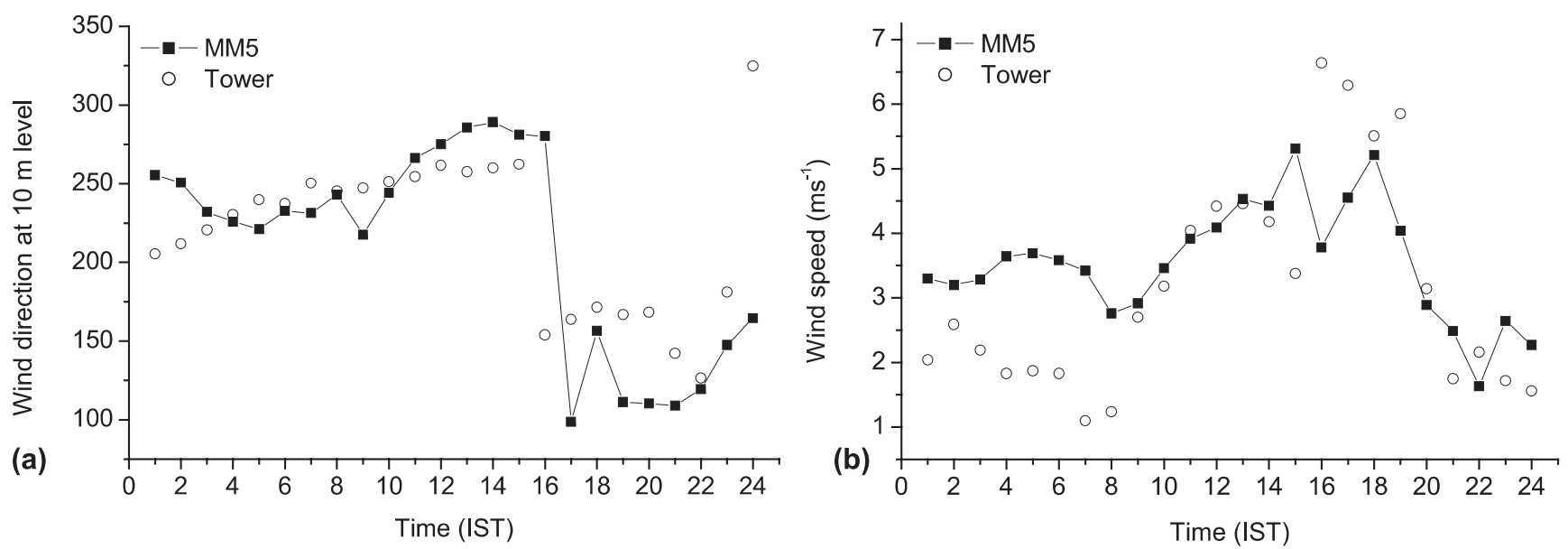

Figure 12. Comparison of simulated and observed (a) wind speed and (b) wind direction at $10 \mathrm{~m}$ level at numerical grid corresponding to Anupuram experimental site on 1 July 2001.

summer case than in the SW-monsoon and winter cases, thereby promoting the local convective cell to develop more intensely in summer. However, it is clearly seen that in all the cases studied, the sea breeze is found to set late in the model as compared to the observations. The sea breeze circulation is primarily forced by the land-sea temperature contrast. Since the sea surface temperature does not vary much during the day, it is attributed mainly to the land temperature evolution in response to the solar radiation and its partitioning at the surface. Thus the model sea breeze onset and its characteristics depend on the evolution of land temperature and surface heat fluxes. In the absence of measured radiation the diurnal surface air temperature (at $2 \mathrm{~m}$ level) is compared with the corresponding model temperature (figure 16) for 24 May '03 and 1 July '01 cases. It is seen that the model temperatures are lower than the observations by about 1 to $2^{\circ} \mathrm{C}$ and there appears some initialization error. Although the model initial values agree with radiosonde observations, there is some bias close to the surface as can be seen from the surface wind and temperature at 00 IST (figures 6, 12, 14, 16). Assimilation of available micro-meteorological observations of Kalpakkam in the model did not improve the initial conditions greatly as it is a single point observation. Hence to resolve this problem, a mesonetwork of automatic weather stations is planned in the Chennai-Kalpakkam-Sriharikota region and efforts are directed to assimilate these highdensity boundary layer observations in the model for better initial conditions for regional weather prediction.

\section{Conclusion}

A simulation study has been carried out to understand the seasonal characteristics of the sea breeze circulation and its impact on regional wind flow and boundary layer structure at the tropical coastal site. Kalpakkam for application to atmospheric dispersion prediction and radiological impact assessment studies. The PSU/NCAR mesoscale atmospheric model MM5 with three interactive nested domains is used in the study. Three cases in summer, SW monsoon and winter seasons have been investigated when the synoptic flow at the site is westerly, southwesterly and northeasterly respectively.

The simulations reveal a consistent diurnal oscillation of the near-surface winds and mixing depth along the coastal regions of India indicating the presence of land-sea breeze circulations and their influence on the local weather several hundred kilometers inland. The characteristics of the coastal atmospheric circulation are studied in more detail over the Kalpakkam region on the east coast using a high-resolution model domain. Many differences are noticed in the three cases of simulation in respect of onset, strength, duration, intensity and inland penetration of sea breeze. It is seen that in the summer case, the development of sea breeze and its progress is very early with larger horizontal and vertical extents due to high land-sea temperature contrast and weak synoptic wind. The strength of the sea breeze is about $6 \mathrm{~m} \mathrm{~s}^{-1}$ and its inland extent is nearly $90 \mathrm{~km}$ in summer. The intensity measured by sea breeze vertical currents is seen as being higher during this off-shore convergence case than in the other two seasonal cases. The sea 

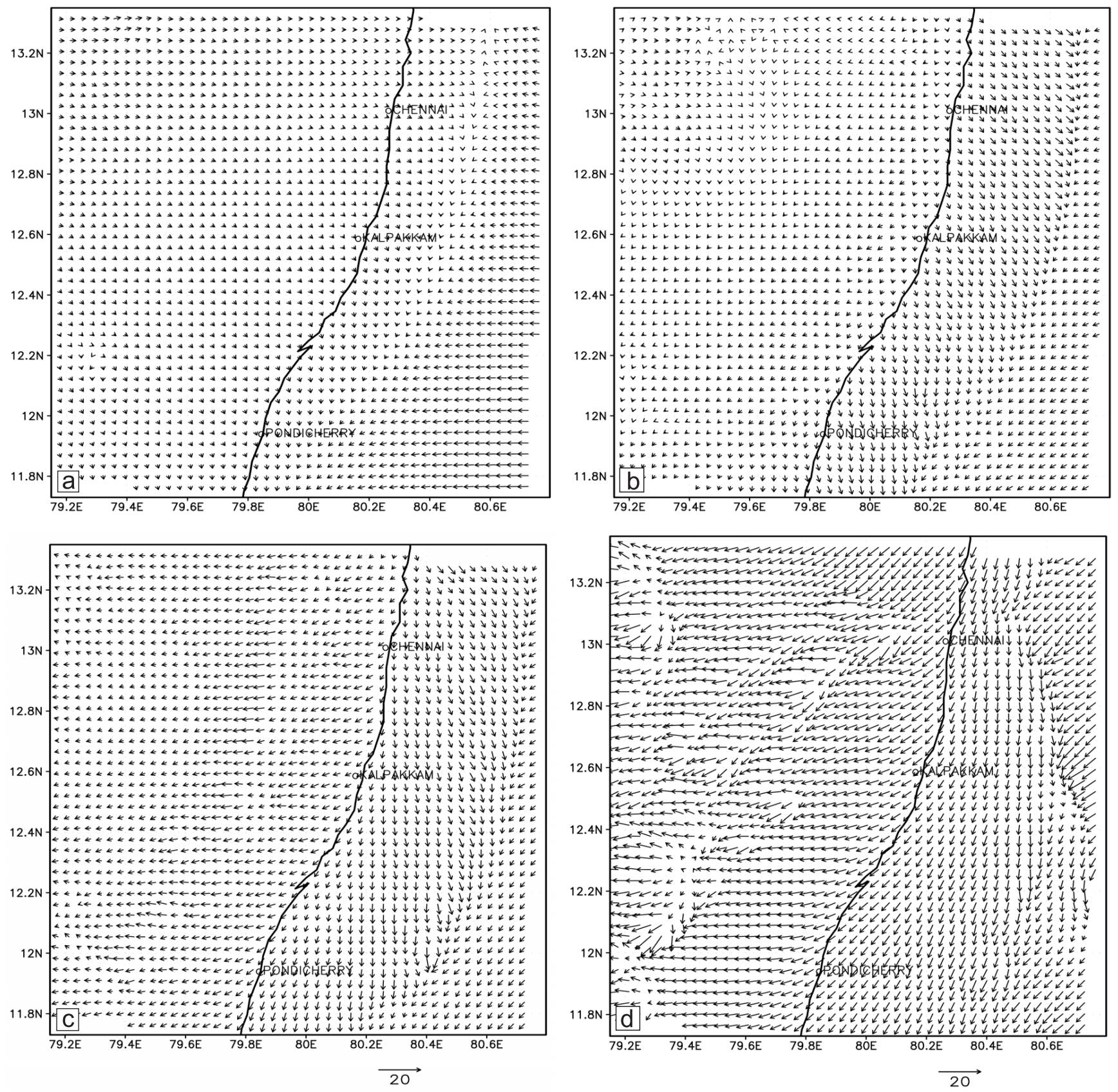

Figure 13. Simulated surface wind in the Kalpakkam region at (a) 0400 IST, (b) 1000 IST, (c) 1200 IST and (d) 1600 IST respectively on 2 February 2003

breeze development is very much delayed in the SW monsoon case, which may be due to the strong opposing synoptic wind. The extent of sea breeze is only about $20 \mathrm{~km}$ inland in the SW monsoon case. The synoptic wind in February is onshore (northeasterly) at Kalpakkam, the sea breeze onset is simulated at 1200 IST and its inland extent is $60 \mathrm{~km}$. The sea breeze strength is simulated as $6 \mathrm{~m} \mathrm{~s}^{-1}$ in summer, $5.5 \mathrm{~m} \mathrm{~s}^{-1}$ in southwest monsoon and $5 \mathrm{~m} \mathrm{~s}^{-1}$ in winter seasons respectively.

The model results indicate modification in the coastal PBL and formation of internal boundary layer at the coast due to sea breeze occurrence. The simulated TIBL height varied at $250 \mathrm{~m}$ in the summer case, $100 \mathrm{~m}$ in the SW monsoon case and $200 \mathrm{~m}$ in the winter case respectively. The horizontal extent of TIBL also varied in different seasons according to the sea breeze development. The downwind spread of TIBL is simulated as $40 \mathrm{~km}$ in summer, $15 \mathrm{~km}$ in SW monsoon and $25 \mathrm{~km}$ in winter cases respectively. Model results are compared with radiosonde observations in the larger domain and with experimental observations in the Kalpakkam region. The model could fairly simulate 

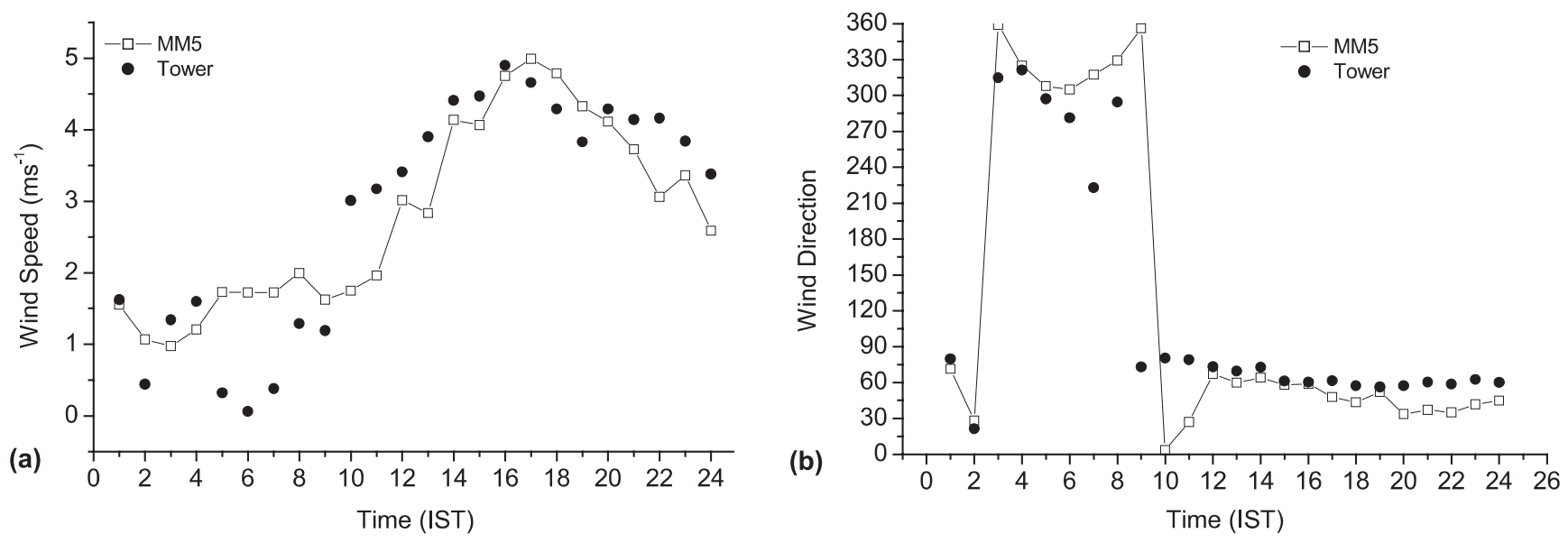

Figure 14. Comparison of simulated and observed (a) wind speed and (b) wind direction at $10 \mathrm{~m}$ level at the model grid corresponding to Anupuram experimental site on 2 February 2003.

Table 2. Simulation results in different seasons.

\begin{tabular}{|c|c|c|c|}
\hline Parameter & $\begin{array}{c}\text { Summer } \\
\text { (24 May 2003) }\end{array}$ & $\begin{array}{l}\text { South-west monsoon } \\
\text { (1 July 2001) }\end{array}$ & $\begin{array}{c}\text { Winter } \\
\text { (2 February 2003) }\end{array}$ \\
\hline Minimum temperature & $302.56 \mathrm{~K}$ & $298.20 \mathrm{~K}$ & $295.38 \mathrm{~K}$ \\
\hline Maximum temperature & $310.52 \mathrm{~K}$ & $307.18 \mathrm{~K}$ & $302.69 \mathrm{~K}$ \\
\hline Net radiation & $750.28 \mathrm{~W} \mathrm{~m}^{-2}$ & $696.23 \mathrm{~W} \mathrm{~m}^{-2}$ & $693.54 \mathrm{~W} \mathrm{~m}^{-2}$ \\
\hline Ground heat flux & $7.66 \mathrm{~W} \mathrm{~m}^{-2}$ & $77.47 \mathrm{~W} \mathrm{~m}^{-2}$ & $135.05 \mathrm{~W} \mathrm{~m}^{-2}$ \\
\hline Sensible heat flux & $338.52 \mathrm{~W} \mathrm{~m}^{-2}$ & $339.51 \mathrm{~W} \mathrm{~m}^{-2}$ & $154.79 \mathrm{~W} \mathrm{~m}^{-2}$ \\
\hline Latent heat flux & $404.1 \mathrm{~W} \mathrm{~m}^{-2}$ & $279.25 \mathrm{~W} \mathrm{~m}^{-2}$ & $403.71 \mathrm{~W} \mathrm{~m}^{-2}$ \\
\hline Onset of sea breeze & 13:00 h IST & 16:30 h IST & 14:00 h IST \\
\hline Strength of sea breeze & $6.0 \mathrm{~m} \mathrm{~s}^{-1}$ & $5.5 \mathrm{~m} \mathrm{~s}^{-1}$ & $5 \mathrm{~ms}^{-1}$ \\
\hline Vertical wind speed & $2.0 \mathrm{~m} \mathrm{~s}^{-1}$ & $60 \mathrm{~cm} \mathrm{~s}^{-1}$ & $55 \mathrm{~cm} \mathrm{~s}^{-1}$ \\
\hline Divergence $\left(\mathrm{s}^{-1}\right)$ & $-100 \times 1.0 \mathrm{e}^{-5} \mathrm{~s}^{-1}$ & $-25 \times 1.0 \mathrm{e}^{-5} \mathrm{~s}^{-1}$ & $-15 \times 1.0 \mathrm{e}^{-5} \mathrm{~s}^{-1}$ \\
\hline Extent of sea breeze & $90 \mathrm{~km}$ & $20 \mathrm{~km}$ & $60 \mathrm{~km}$ \\
\hline Duration of sea breeze & $13: 00$ to $22: 00$ IST & $16: 30$ to $22: 00$ IST & 11:00 to $02: 00$ IST \\
\hline TIBL depth & $250 \mathrm{~m}$ & $100 \mathrm{~m}$ & $150 \mathrm{~m}$ \\
\hline Horizontal extent of TIBL & $40 \mathrm{~km}$ & $15 \mathrm{~km}$ & $25 \mathrm{~km}$ \\
\hline
\end{tabular}

some of the essential characteristics of the coastal atmospheric phenomena that have a strong influence on the pollution dispersion in the region. However, more number of case studies from each season would be required to come to reasonable conclusions. Nevertheless, variations in the simulated flow cases indicate the presence of complex dispersion conditions present at the site. Some discrepancies are noticed in the simulation; for example, the onset time of the sea breeze is delayed by about $1 \frac{1}{2}$ hours, which may be due to the constraints of chosen horizontal and vertical resolutions and the initial meteorological data. It is known that the simulations from meso-scale models are sensitive to the initial condition. A highresolution initial condition would be needed for the model to capture the meso-scale details of the flow and to resolve the fine features of the local circulations. In this regard, some preliminary experiments are made to assimilate the available observations of Karaikal, Chennai and Machilipatnam along the coast using the objective interpolation scheme in MM5 to prepare a high-resolution analysis. However, no improvement is noticed in the MM5 analyses. This is perhaps due to the reason the observation locations are not closely spaced and have been already utilized in the NCEPFNL analyses. Efforts are underway to incorporate high-density observations from meso-network and special experiments in the model for better initial conditions and improvement in local weather prediction. The error/model bias can also 


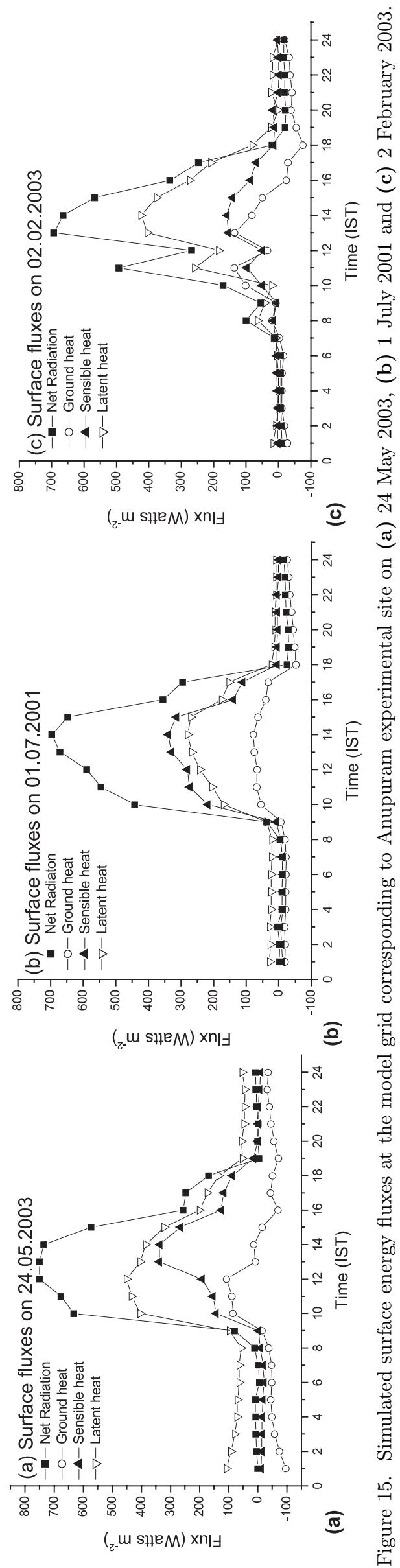

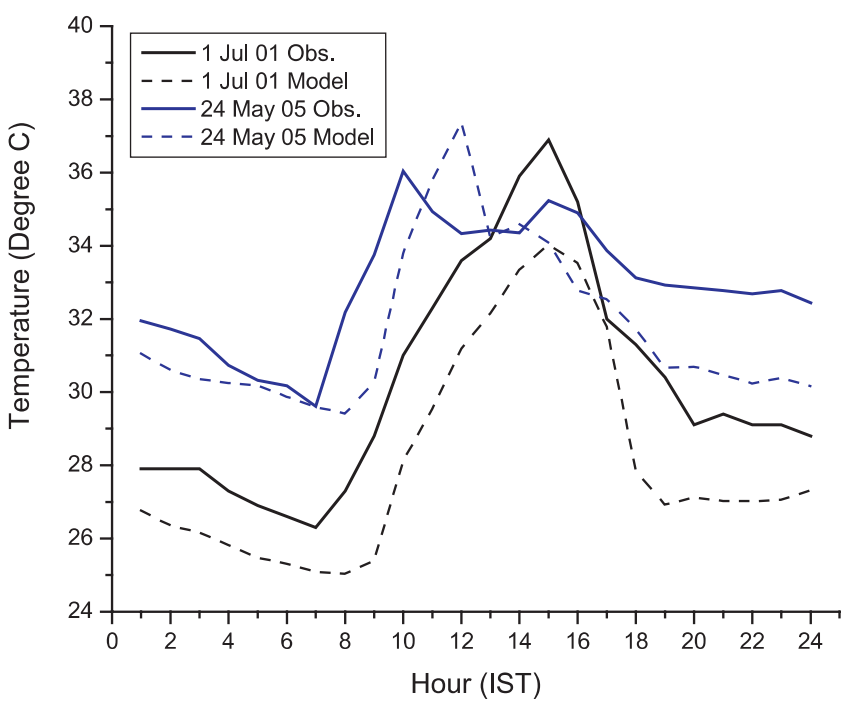

Figure 16. Comparison of model predicted (dashed) and observed (continuous) temperature variation for 1 July 2001 (black) and 24 May 2003 (blue).

be attributed to the subgrid scale effects related to unresolved variations in topographic features arising from surface representation and inadequate treatment of convection and boundary layer turbulence, which has to be investigated further. The turbulent diffusion in the model is treated using level-2 approximation, which is a local diffusion scheme. The simulation of vertical mixing associated with sea breeze circulation may require application of certain non-local diffusion approaches. In this regard sensitivity experiments would be carried out with several other available PBL schemes in the framework of MM5 for reasonable simulation of sea breeze characteristics. The surface data are being generated from Indian sources so that the local soil and vegetation types are represented in the model.

\section{Acknowledgements}

Authors thank Dr. Baldev Raj, Director, IGCAR, Sri S Govindarajan, Associate Director, Safety Group and Dr. R Indira, Head, Radiological Safety Division, IGCAR for the encouragement in carrying out the study and the support for the Atmospheric Studies program. The authors duly acknowledge the anonymous reviewers for suggesting improvements in the manuscript.

\section{References}

Arritt R W 1987 The Effect of Water Surface Temperature on Lake Breezes and Thermal Internal Boundary Layers; Boundary-Layer Meteor. 40 101-125. 
Atkins N T, Wakimoto R M and Weekwerth T M 1995 Observations of the sea-breeze front during CaPE. Part II: Dual Doppler and aircraft analysis; Mon. Wea. Rev. 123 944-969.

Atkins T and Wakimoto R M 1997 Influence of the synoptic scale flow on sea breezes observed during CaPE; Mon. Wea. Rev. 125 212-2130.

Atkinson B W 1981 Meso-scale Atmospheric Circulations; Academic Press, 496 pp.

Bechtold P, Pinty J P and Mascart P 1991 A numerical investigation of the influence of large scale winds on sea breeze and inland breeze type circulations; J. Appl. Meteor. 30 1268-1279.

Chen F and Dudhia J 2001 Coupling an advanced landsurface model with the Penn State-NCAR MM5 modeling system. Part I: Model implementation and sensitivity; Mon. Wea. Rev. 129569.

Cooper H J, Smith E A and Rubes M T 1998 Relevance of Surface Energy Budget within Florida Sea-Breeze Front to Cross-Peninsula Rainwater Runoff Gradient; J. Appl. Meteor. 37 939-950.

Defant F 1950 Theorie der Land-und Seewinde; Arch. Meteor. Geophys. Bioklimatol. Vienna Ser. A 2-3 404425.

Estoque M A 1962 The sea breeze as a function of the prevailing synoptic situation; J. Atmos. Sci. 19 244-250.

Jamima P and Lakshminarasimhan J 2004 Numerical simulation of sea breeze characteristics observed at tropical coastal site, Kalpakkam; Proc. Indian Acad. Sci. (Earth Planet. Sci.) 113(2) 197-209.

Grell G A 1993 Prognostic evaluation of assumptions used by cumulus parameterization; Mon. Wea. Rev. 121764 787.

Grell G A, Dudhia J and Stauffer D R 1994 A description of the fifth-generation Penn State/NCAR mesoscale model (MM5); NCAR Technical Note, NCAR/TN-398+STR, $117 \mathrm{pp}$.

Gryning S E and Batchvarova E 1990 Analytical model for growth of the coastal internal boundary layer during onshore flow; Quart. J. Roy. Meteor. Soc. 116 187-203.

Hunt J C R and Simpson J E 1982 Atmospheric boundary layer over non-homogeneous terrain; In: Engineering Meteorology (ed.) E J Plate, Elsevier, 269-318.

Janjic Z I 1990 The step-mountain coordinate: physical package; Mon. Wea. Rev. 118 1429-1443.

Jianmin Ma 1997 Numerical modeling of sea-breeze circulation over Cleveland Bay; Aust. Meteor. Mag. 46 1-13.

Krishna Murthy K, Krishna Murthy B V and Prabha R Nair 1992 Sea breeze front effects on boundary layer aerosols at a tropical coastal station; J. Appl. Meteor. 32 11961205 .

Liu H C, Johnny L and Cheng A Y S 2001 Internal boundary layer structure under sea breeze conditions in Hong Kong; Atmos. Environ. 35 683-692.

Lu R and Turco R P 1994 Air pollutant transport in a coastal environment. Part I: Two-dimensional simulations of sea breeze and mountain effects; J. Atmos. Sci. 51(15) 2285-2308.

Lyons W A, Tremback C J and Pielke R A 1995 Applications of RAMS to provide input to photochemical grid models for LMOS; J. Appl. Meteor. 34 $1762-1784$.
Mahrer Y and Pielke R A 1977 The effects of topography on sea and land breezes in a two-dimensional numerical model; Mon. Wea. Rev. 105 1151-1162.

Melas Dimitrios, Ioannis C Ziomas and Zerefos Christos J 1995 Boundary layer dynamics in an urban coastal environment under sea breeze conditions; Atmos. Environ. 29(24) 3605-3617.

Nair S and Narayanan V 1980 Diurnal variation of lower tropospheric winds $(0-3 \mathrm{~km})$ over Thumba during 1820 August 1976; Mausam 31 409-414.

Narayanan V 1967 An observational study of sea breeze at an equatorial coastal station; Ind. J. Meteor. Geophys. 18 497-504.

Pielke R A and Uliasz M 1998 Use of meteorological models as input to regional and mesoscale air quality models limits and strengths; Atmos. Environ. 32 1455-1466.

Pielke R A 1974 A Three Dimensional Numerical Model of the Sea Breezes in the South Florida; Mon. Wea. Rev. 102 115-139.

Ramanatham Y and Subbaramayya I 1963 The sea breeze at Visakhapatnam; Ind. J. Meteor. Geophys. 241-248.

Rao P A and Fuelberg E 2000 An investigation of convection behind the Cape Canaveral Sea-Breeze Front; Mon. Wea. Rev. 128 3437-3458.

Seaman N L 2000 Meteorological modeling for air quality assessment; Atmos. Environ. 34 2231-2259.

Shafran P C, Seaman N L and Gayno G A 2000 Evaluation of numerical predictions of boundary layer structure during the Lake Michigan Ozone Study (LMOS); J. Appl. Meteor. 39 412-426.

Simpson J E 1987 Gravity currents: In the environment and the laboratory; John Wiley and Sons.

Simpson J E 1995 Sea breeze and local winds Cambridge; University Press, 234 pp.

Sivaramakrishnan S and Venkatesan R 2002 Coastal Atmospheric Boundary Layer Experiment (CABLE 2001), A Report submitted to AERB, Mumbai, India.

Stauffer D R, Seaman N L, Warner T T and Lario A M 1993 Application of an atmospheric simulation model to diagnose air pollution transport in the Grand Canyon region of Arizona; Chem. Eng. Commun. 121 9-26.

Stull R B 1988 An Introuduction to Boundary Layer Meteorology; (Dordrecht: Kluwer Academic Publishers).

Thara V Prabha, Venkatesan R and Natarajan A 1999 Simulation of meteorological fields over a land-water-land terrain and comparison with observations; BoundaryLayer Meteor. 91(2) 227-257.

Thara V P, Venkatesan R, Mursch-Radlgruber E, Rengarajan G and Jayanthi N 2002 Thermal Internal Boundary Layer characteristics at a tropical coastal site as observed by a mini-SODAR under varying synoptic conditions; Proc. Indian Acad. Sci. (Earth Planet. Sci.) 111(1) $63-77$.

Venkatesan R, Sitaraman V and Thara V Prabha 2000 Mesoscale Atmospheric Model (MAM-I) for sea breeze simulation: Documentation and operating manual. Research Report IGC-217, Indira Gandhi Centre for Atomic Research, Kalpakkam.

Willmott C J, Ackleston S G, Davis R E, Feddema J J, Klink K M, Legates D R, Donnell J O and Rowe C M 1985 Statistics for the evaluation and comparison of models; J. Geophys. Res. (C5) 8995-9005. 